Agro-Science Journal of Tropical Agriculture, Food, Environment and Extension Volume 19 Number 3 (July 2020) pp. 19 - 24

ISSN 1119-7455

\title{
SOCIO-ECONOMIC DETERMINANTS OF HOME GARDENING PRACTICES AMONG HOUSEHOLDS IN UNIVERSITY OF NIGERIA COMMUNITY: HECKMAN DOUBLE STAGE SELECTION APPROACH
}

\author{
*Adeosun K.P., Nnaji A.P. and Onyekigwe C.M. \\ Department of Agricultural Economics, University of Nigeria, Nsukka, Nigeria \\ *Corresponding author's email: paul.adeosun@unn.edu.ng
}

\begin{abstract}
The study identified different food crops, fruits and vegetables found around homes, constraints of home garden practice, and also socio-economic factors influencing home garden contribution to household's food consumption. Primary data were collected for the study. Two-stage random sampling procedure was used to select80 respondents for the study. The data collected were analyzed using descriptive statistics such as percentages, means and Heckman sample selection model. The result shows that different food crops, fruits and vegetables that are majorly planted by most respondents include maize (82.5\%), mango (50.0\%) and fluted pumpkin leaf (81.2\%) which are used for different purposes such as food, medicine and ornaments. The result from the Heckman two-stage analysis shows that in the first stage marital status (-1.7912) and female household size (0.3748) are statistically significant at 1\% probability level, while income (4.6e-06) was statistically significant at $5 \%$ probability level on the home gardening practice. In the second stage, experience in home gardening (1.1089) was statistically significant at 1\% probability level on contributions of home gardening to household's food consumption. The study revealed that home garden practices was constrained by factors such as high cost of inputs, inadequate access to water, pest and diseases etc. The government and concerned agencies such as NGOs should provide and subsidize these promptly to households as incentives to increase their home garden practices. The study recommends there should be institutionalization of those socioeconomic factors that promote home gardening practice.
\end{abstract}

Key words: home-gardening, food consumption, Heckman-model

\section{INTRODUCTION}

There is problem of hunger and malnutrition faced by people living in developing countries under substandard living conditions (Galhena et al., 2013). According to Galhena et al. (2013), over half billion of people in the world are faced with food insecurity and with global population expected to increase to 9 billion by 2050 pose a further serious danger on food security of the world. In order to meet world food security proposition, food production is estimated to increase by $70 \%$ in order to meet average caloric requirement of the world's population by year 2050 . Hence, there will be continuous needs to increase food production. Thus, different numbers of strategies to increase food production and food security are needed (Marsh, 1998; Idrisa et al., 2008) and home gardening is one of the suggested strategies.

Decades ago, small plots of land near houses have been used by family as home garden and it forms part of household's food system (Okvat and Zautra, 2011; Baiyegunhi, 2015). Home garden can be described as owned, rented or borrowed land, either on the same property as the residence or on adjacent land such as a vacant lot by household (Gray et al., 2014; Taylor and Lovell, 2014). A prominent structural characteristic of the home garden is the great diversity of species with many life forms varying from fruit crops, e.g., banana, plantain, mango, coconut, oil palm and food crops, e.g., cassava, sweet potatoes, cocoyam, yam and vegetables etc. (Zick et al., 2013; Ibrahim et al., 2019). Besides, home gardening helps to increase food production. This is encapsulated in year-round production of food and a wide range of other products such as fuel wood, fodder, spices, medicinal plants and ornamentals (Wang and MacMillan, 2013; Tamiru, et al., 2016). It enhances food and nutritional security in many socioeconomic and political situations. It also improves family health and human capacity, empowering women and preserving indigenous knowledge and culture (Hawkins et al., 2013; Scott et al., 2014). Owing to the role of home garden in food security, households have continued to practice it year after year. Households find home garden to be important to provision of varieties and nutritive foods that meet household's food and nutrition security, improvement of health (provision of medicinal plants), income generation as parts of the produce such as vegetables and fruits are offer for sale, shelter, climate regulation, and shade (Guitart et al., 2012). 
Consequently, home gardening has been found to be important complementary source of foods apart from main farms contributing to household's food security and livelihoods. It remains the most food access close to households and readily available (Reyes-García et al., 2012; Baiyegunhi, 2015). Reyes-García et al. (2012) argued that home gardening is efficient in cash and energy flow. Thus, home gardening enables dissipation of concerns about hike in food prices, destructive impact of agricultural technologies on the environment as well as the health consequences of pesticides on food (Poulsen et al., 2014; Lin et al., 2017).

In Nigeria, many societies have traditionally simulated forest conditions in their farms and gardens in order to obtain the beneficial effects of forest structures particularly in the urban cities. According to Reyes-García et al. (2012), home gardening focuses majorly on edible crops. It provides easy dayto-day access to an assortment of fresh and nutritious foods for the household and accordingly those homes obtained more than $50 \%$ of the vegetables, fruits, and tubers, from their garden (Tamiru et al., 2016). Galhena et al. (2013) reported that home gardening has been tested and proved locally to be a good strategy widely accepted to help solve the problem of food insecurity, alleviate hunger and increase food production particularly in many developing countries, Nigeria inclusive.

Furthermore, some individuals who possess home garden leave it unattended as they feel there is no need for practicing home garden as they lack information on its benefits (FAO, 2004; ReyesGarcía et al., 2014). FAO (2004) also reported that some individuals who practice home garden do it to pass out time and don't give enough attention required by the home garden, thus, not getting the maximum benefits that can be obtained from these home gardens. Hence, this study aims to fill these gaps in knowledge. Based on the foregoing, the study identified different food crops, fruits, and vegetables that are cultivated in the home garden and also examined the socio-economics factors influencing home gardening practice.

\section{MATERIALS AND METHODS \\ Study Area}

The study is carried out in the University of Nigeria, Nsukka because there are a lot of home garden practices by the University staff particularly those who live in the staff quarters because of the peculiarity of the household composition. There is enough space of land around the houses to practice home garden. They grow different kind of food crops, vegetables, and fruit trees around the houses. The University is located on 871 ha of hilly savannah in the town of Nsukka, about $80 \mathrm{~km}$ north of Enugu, and enjoys a very pleasant and healthy climate (NPC, 2006). Additionally, 209 hectares of arable land are available for an experimental agricultural farm and
207 ha for staff housing development in the campus. The University has house units of 530 for senior staff and 62 units for junior staff (University of Nigeria Housing Unit, 2019).

\section{Sample and Sampling Procedure}

Simple random sampling was used to select eight staff streets from the 18 staff streets within the campus which include Ezenweze, Cartwright, Ikejiani, Fulton Avenue, Eni-Njoku, Umukanka, Alvan Ikoku and Ezeala Streets. The streets have almost equal number of residential houses. Consequently, 10 households were randomly selected from each street to make 80 households for the study.

\section{Data Collection}

The instrument used for the data collection was a structured questionnaire. Variables measured includes: different food crops and vegetables planted in the home garden, household's perception of home garden contributions to household's food consumption and constraints of home garden practice. Also, information socio-economic characteristics such as age, gender, marital status and household's size are collected.

\section{Data Analysis}

Data were analyzed using both descriptive statistics (i.e., mean and percentages) and inferential statistics (i.e., Heckman selection model). The model for inferential statistics is specified below.

\section{Model Specification \\ Heckman sample selection model}

Heckman model combines Probit and linear regression model together in a single model. Heckman model is able to observe households in the sample that do not practice home gardening. Hence, it truncates the households that do not practice home gardening to be able to assess home gardening contribution to household food consumption based on the household that practiced home gardening (positive observation). Thus, the Heckman sample selection model is composed of the continuous component $f Y_{2} \mid \mathrm{U}=1$ and the discrete component $P_{r} Y_{1}(U)$. Suppose that the regression model of primary interest is:

$$
y_{2}^{*}=X_{1}^{T} \beta+\varepsilon_{i}, i=1, \ldots \ldots \ldots \ldots \ldots, 8
$$

However, due to a certain selection mechanism;

$$
u_{1}^{*}=w_{1}^{T} \gamma+\eta_{1}, i=1, \ldots \ldots \ldots \ldots \ldots, 8
$$

We observe only $\mathrm{N}_{\mathrm{i}}$ out of $\mathrm{N}$ observations $\mathrm{y}_{1}{ }^{*}$ for which

$$
\mathrm{u}_{\mathrm{i}}^{*}>0: \mathrm{u}_{i}=I\left(\mathrm{u}_{i}^{*}>0\right)
$$$$
y_{i}=y_{i}^{*} \mathrm{u}_{i}
$$

Probit model: $P_{r} Y_{1}(U=\mathrm{u})=\left\{\Phi\left(w_{\gamma_{1}}^{T}\right)\right\}^{\mathrm{u}}\{\Phi$

$$
\log _{y_{1}}=\mathrm{x} \beta+v_{i} \text { if } z \alpha_{i}+\mathrm{u}_{i}>0
$$

$y_{1}=0$ if $z \quad \alpha_{i}$

$$
i=1, \ldots \ldots \ldots, m
$$

Ordinary Least Square in Heckman selection model:

$$
\mathrm{E}\left(\mathrm{Y} 2 \mid \mathrm{U}^{*}>0, x, w\right)=\mathrm{x}_{i}^{T} \beta+\rho \sigma \lambda\left(w_{\gamma_{2}}^{T}\right)
$$


where $Y_{1}$ is binary outcome ( 1 if household practices home gardening or 0 otherwise), $\mathrm{Y}_{2}$ is dependent variable (household's proportion of food consumption from home gardening per month on the scale of 1 to 10). The respondents were asked to score the output from home garden to their household food consumption on the scale of 1 to 10 . The dependent variable was measured in percentage. Hence the scale is converted to percentage. Then, $\mathrm{X}_{1}, \ldots, \mathrm{X}_{9}$ are independent variables/explanatory variables which explain the socio-economic factors that affect home gardens' contribution to household food consumption; $X_{1}$ is age of respondent (in years), $X_{2}$ is sex of respondent (male $=1$, female $=0), X_{3}$ is male household size (numbers), $\mathrm{X}_{4}$ is female household size (numbers), $\mathrm{X}_{5}$ is income (Naira), $X_{6}$ is marital status (married $=1$, otherwise $=0), X_{7}$ is years of formal education (years), $\mathrm{X}_{8}$ is garden size (ha), $\mathrm{X}_{9}$ is years of practice of home gardening (years), and $\mu$ is error term.

\section{RESULTS AND DISCUSSION}

\section{Food Crops in Home Gardens and Their Uses}

Table 1 shows that the common food crops grown in home garden were maize, cassava, yam, potato, tomato, melon, cocoyam, cucumber, ginger, three leaf yam, okro, garden egg, black beans, aloe Vera and pepper (Adebisi et al., 2019). It is indicated that majority $(82.5 \%)$ of the respondents grew maize in their garden. The second major food crop grow by the respondents was cassava as indicated by $66.2 \%$ of the respondents. Also, cocoyam and yam were grown by $23.8 \%$ and $26.2 \%$ of the respondents respectively. Okro was grown by $17.5 \%$ of the respondents. Tomato and garden egg were grown by $16.2 \%$ and $15.0 \%$ of the respondents, respectively. However, cucumber $(1.2 \%)$, ginger $(1.2 \%)$, three-leaf yam $(3.8 \%)$ and aloe Vera $(1.2 \%)$ were the least grown food crops by the households. All the crops grown are used for household's food consumption except aloe Vera that is use for medicinal purpose.

Table 2 shows different fruits present in home garden. About $27.5 \%$ of the respondents had pawpaw in their garden, $50.0 \%$ had mango, $13.5 \%$ had cashew, $30.0 \%$ had avocado while plantain was grown by $35.0 \%$ of the respondents and they were all use as for food. Also, 33.8\% of the respondents had orange. Fruits like sour sap (7.5\%), Moringa (7.5\%), coconut $(1.2 \%)$, African cherry $(2.5 \%)$ were not common in-home gardens. Most of the fruits were used for food except few like mango, avocado were used for both food and medicinal purpose. Moringa and coconut were used mainly for medicinal purpose.

Table 3 shows that the majority $(81.2 \%)$ of the respondents' plant fluted pumpkin popularly known as "ugu" and they all used it for food. About $2.5 \%$ of the respondents used it as medicine. The second vegetable vastly grown by respondents was green which was grown by $32.5 \%$ and also used for food. Bitter leaf was grown by $17.5 \%$ of the respondents, also used for food. Scent leaf was grown by $16.2 \%$ of the respondents and they all used it for food. However, $2.5 \%$ of the respondents grew it and use it as medicine. African rosewood leaves popularly known as "oha" was grown by $6.2 \%$ of the respondents and used as food too. Jute leaves (ewedu), wild spinach (utazi), bush buck (ukazi) and lemon grass were grown by $2.5 \%, 1.2 \%, 1.2 \%$ and $1.2 \%$ each by the respondents, respectively. These are all used for food except the lemon grass which was used as medicine.

From the result of the study, different food crops such as cassava, cocoyam, sweet potatoes, yam, just to mention a few are planted in the home garden. This is supported by finding of Zick et al. (2013), that edible food crops are the major composition of home garden. Likewise, the result of study is accordance to the findings of Wang and MacMillan (2013) and Tamiru et al. (2016) that most produce from home garden are used for food, medicine and ornamental. Also, Reyes-Garcia et al. (2012) supported the result of the findings that vegetables are also part of home garden composition.

Table 1: Types of crops grown by respondents in the home garden $(n=80)$

\begin{tabular}{lll}
\hline $\begin{array}{l}\text { Important food crops } \\
\text { grown by respondents }\end{array}$ & Uses & $\begin{array}{l}\text { Percent- } \\
\text { age** }\end{array}$ \\
\hline Maize (Zea mays) & Food & 82.5 \\
Cassava (Manihot utilisima) & Food & 66.2 \\
Yam (Dioscorea spp) & Food & 23.8 \\
Potato (Solanum tuberosum) & Food & 7.5 \\
Tomato (Solanum lycopersicum) & Food & 16.2 \\
Melon (Citrullus lanatus) & Food & 5 \\
Cocoyam (Colocasia esculenta) & Food & 26.2 \\
Cucumber (Cucumis sativus) & Food & 1.2 \\
Ginger (Zingiber officinale) & Food & 1.2 \\
Three-leaf yam (Dioscorea dumetorum) & Food & 3.8 \\
Okro (Abelmoschus esculentus) & Food & 17.5 \\
Garden egg (Solanum melongena) & Food & 15 \\
Black beans (Phaseolus vulgaris) & Food & 8.7 \\
Aloevera (Aloe barbadensis) & Medicine & 1.2 \\
Pepper (Capsicum Anumm) & Food & 13.8 \\
\hline Fid Survey, 2016; & &
\end{tabular}

Field Survey, 2016; **multiple responses

Table 2: Details of fruits, and their uses by respondents $(n=80)$

\begin{tabular}{lll}
\hline $\begin{array}{l}\text { Important fruits present } \\
\text { in the home garden }\end{array}$ & Uses & $\begin{array}{l}\text { Percent- } \\
\text { age** }\end{array}$ \\
\hline Paw paw (Carica papaya) & Food & 27.5 \\
Mango (Mangifera indica) & Food & 50 \\
Mango (Mangiferaindica) & Medicine & 1.2 \\
Cashew (Anacardiun occidentale) & Food & 13.8 \\
Avocado pear (Pyrusspp) & Food & 30 \\
Avocado pear (Pyrusspp) & Medicine & 1.2 \\
Plantain (Musa spp) & Food & 35 \\
Orange (Citrus sinensis) & Food & 33.8 \\
Oil palm (Elaeis guineensis) & Food & 11.2 \\
Soursap(Annona muricata) & Food & 7.5 \\
Moringa (Moringa oleifera) & Medicine & 7.5 \\
Banana (Musa spp.) & Food & 25 \\
Tangerine (Citrus tangerina) & Food & 1.2 \\
African cherry (Chrysophyllum albidum) & Food & 2.5 \\
Guava (Psidiun guajava) & Food & 3.8 \\
Coconut (Cocos nucifera) & Medicine & 1.2 \\
\hline
\end{tabular}

Field Survey, 2016, **multiple response 
Table 3: Details of vegetables, and their uses by respondents in the home garden $(n=80)$

\begin{tabular}{lll}
\hline $\begin{array}{l}\text { Important vegetables } \\
\text { grown by respondents }\end{array}$ & Uses & $\begin{array}{l}\text { Percent- } \\
\text { age** }\end{array}$ \\
\hline $\begin{array}{l}\text { Fluted pumpkin leaf } \\
\text { (Telfairia occidentalis) }\end{array}$ & Food & 81.2 \\
$\begin{array}{l}\text { Fluted pumpkin leaf } \\
\text { (Telfairia occidentalis) }\end{array}$ & Medicine & 2.5 \\
Scent leaf (Ocimum gratissimum) & Food & 16.2 \\
Scent leaf (Ocimum gratissimum) & Medicine & 2.5 \\
African rosewood leaves & & \\
(Hagenia abyssinica) & Food & 6.2 \\
Green (Amaranthus hybridus ) & Food & 32.5 \\
Bitter leaf (Vernonia amygdalina) & Food & 17.5 \\
Water leaf (Talinum triangulare) & Food & 13.8 \\
Jute leaves (Corchorus spp.) & Food & 2.5 \\
Wild spinach (Gnetum africanum) & Food & 1.2 \\
Bush buck (Gongronema latifolium) & Food & 1.2 \\
Lemon grass (Cymbopogon martinil) & Medicine & 1.2 \\
\hline \multicolumn{2}{l}{ Field Survey, 2016, ** multiple responses } &
\end{tabular}

\section{Influence of Socioeconomic Factors on Home} Gardening Practice

Heckman sample selection model results presented in Table 4 captured both the home gardening practice and the proportion of household food consumption coming from home garden. The model is good fit with a significant $\mathrm{chi}^{2}=28.89$ Prob $>$ chi $2=0.0007$.

First, marital status (-1.7912) is statistically significant and has a negative relationship with home gardening practice at $1 \%$ probability level. This is against a-priori expectation and this could be interpreted to mean that married households have less time because major shares of their time are allocated to official jobs, children care and other home duties. Marital status of the garden caretaker was reported to be among variables with significant positive influence on home garden participation among some households in the Peruvian amazon (Coomes and Perrault, 2008) which is contrary to the findings. While female household size (0.3748) significantly and positively influenced household's home gardening practice at $1 \%$ probability level. This means household dominated with females will likely involve in home gardening because women are good home managers. This depicts that household with more females' practice home gardening. The reasons may be because they would have more time to devote to home garden practices as most females are not bread winners of the family. This is in line with findings of Schreinemachers et al. (2016), that most women manage their home garden. This is accordance with apriori expectation that women will find the resources from home gardening more useful and supportive. Likewise, Zick et al. (2013) noted that women may find resources from home gardening interesting because it helps in improving household's nutrition, hence, women are households' nutrition managers (Wang and Glicksman, 2013). Income of the household head $(4.60 \mathrm{e}-06)$ is statistically significant $(P<0.05)$ and positively influence home garden practice. The result shows that household with high income will likely invest part of it in home garden. This is consistent with the findings of Shupp et al. (2015), that income also influences home gardening participation. Experience in home gardening $(1.1089)$ is significant $(P<0.001)$ and positively related to the proportion of households share of food coming from home gardening. This is accordance with apriori expectation that household with more experience will have varieties and diversities foods coming from gardening.

Table 4: Influence of socioeconomic factors on home gardening practice and contribution to food consumption

\begin{tabular}{|c|c|c|c|c|}
\hline \multirow[t]{2}{*}{ Variable } & \multicolumn{2}{|c|}{ Home gardening practice } & \multicolumn{2}{|c|}{ Proportions of household food from home garden } \\
\hline & Coefficient & Standard error & Coefficient & Standard error \\
\hline Age & -.0273 & .0180 & -.4322 & .2414 \\
\hline Gender & & & 2.4808 & 4.6351 \\
\hline Marital Status & $-1.7912 * * *$ & .6827 & 4.2362 & 5.8424 \\
\hline Level of education & -.0527 & .0527 & .1790 & .6962 \\
\hline Male household size & -.0101 & .1269 & -1.7248 & 1.3647 \\
\hline Female household size & $3748^{* * *}$ & .1392 & -.2422 & 1.5509 \\
\hline Size of home gardening & 1.3148 & 2.5493 & 35.6384 & 21.6786 \\
\hline Experience of home gardening & .0144 & .0182 & $1.1089 * * *$ & .2407 \\
\hline Income & $4.60 \mathrm{e}-06^{* *}$ & $1.88 \mathrm{e}-06$ & .0000 & .0000 \\
\hline _cons & 2.1762 & 1.1483 & $30.8874 * *$ & 12.7221 \\
\hline Rho & -1.1908 & 0.6977 & -1.71 & 0.088 \\
\hline Wald chi2(9) & $28.89 * * *$ & & & \\
\hline LR chi2(1) & $2.82 *$ & & & \\
\hline Log likelihood & -333.7364 & & & \\
\hline Prob $>$ chi 2 & 0.0007 & & & \\
\hline No of observation & 79 & & & \\
\hline Censored observation & 55 & & & \\
\hline Uncensored observation & 24 & & & \\
\hline
\end{tabular}




\section{Respondents' Perceived Constraints of Home Gardening Practice}

Table 5 shows that pest and diseases attack $(M=4.26)$ was the serious constraint in home garden practice. This may be attributed to the fact that pest and diseases of plants and animals were prevalent in the study area. The next major constraint observed was high cost of inputs $(M=3.74)$. Inputs such as fertilizers, seedlings, implements, etc., are very expensive to purchase. Also, inadequate access to water $(\mathrm{M}=3.65)$ posed as a major constraint as result shows that water was not adequate for cultivation. Besides the major constraints, other serious constraints that caused limitation of home garden practice in the study area were: limited availability of land for farming (3.10), poor access to information about climate change (3.18), postharvest losses (3.48), inadequate storage facilities (3.36), low price of agricultural commodities (3.33), poor market for agricultural commodities (3.25), shortage of family or hired labour (3.58), poor soil fertility and soil erosion (3.05). These really agree with the findings of Shupp et al. (2015) and Lin et al. (2017), who also reported similar factors as barriers to home garden practice. From the responses of interviewees, these factors are considered very serious and that if something is not done about it home garden practice will be limited and the benefit from it will automatically be reduced.

\section{CONCLUSION/RECOMMENDATIONS}

Although tropical home gardens especially those in Africa have not received enough attention from scientist and researchers, they continue to play a vital role in the livelihoods of many households. They are expected to be even of more importance and significance to marginal people as population continues to rise. The study revealed the importance of home gardening to household food consumption. The study showed different components found to be common in home gardening such as vegetables which include fluted pumpkin, scent leaf, green, bitter leaf, and water leaf. Also, arable crops consist of maize, cassava, yam, tomato, cocoyam, okro, and pepper. Whilst fruit consist of pawpaw, mango, avocado pear, plantain, orange and oil palm which are commonly grown by households for food, medicine and ornaments. Likewise, important socioeconomic factors that promote home gardening were identified to be marital status, female household size, experience in home gardening and income. In addition, major factors that constrained home gardening are high cost of input, pest and disease attack, inadequate access to water, limited availability of land for farming and poor soil fertility and soil erosion. Therefore, the study recommended that there should be institutionalization of those socioeconomic factors that promote home gardening practices. The study revealed that home garden practices were constrained by factors such as high
Table 5: Distribution of constraints to home gardening practice $(n=80)$

\begin{tabular}{lll}
\hline Constraints to home garden practice & Mean & $\begin{array}{l}\text { Std. } \\
\text { dev. }\end{array}$ \\
\hline High cost of inputs & $3.74^{*}$ & 1.31 \\
Limited availability of land for farming & $3.10^{*}$ & 1.33 \\
Poor access to information about climate change & $3.18^{*}$ & 1.12 \\
Land ownership & 2.72 & 1.18 \\
Pest and diseases attack & $4.26^{*}$ & 0.85 \\
Post-harvest losses & $3.48^{*}$ & 1.17 \\
Inadequate storage facilities & $3.36^{*}$ & 1.25 \\
Low price of agricultural commodities & $3.33^{*}$ & 1.08 \\
Theft & 2.12 & 1.14 \\
Infertile land & 2.12 & 1.14 \\
Poor market for agricultural commodities & $3.25^{*}$ & 1.01 \\
Inadequate access to water & $3.65^{*}$ & 1.54 \\
Shortage of family or hired la bour & $3.58^{*}$ & 1.28 \\
Poor soil fertility and soil erosion & $3.05^{*}$ & 1.23 \\
\hline Source: Field Survey, 2016, *Serious & &
\end{tabular}

Source: Field Survey, 2016, *Serious

cost of inputs, inadequate access to water, pest and diseases etc. Hence, government and concerned agencies such as NGOs should provide and subsidize these promptly to households as incentives to increase their home garden practices.

\section{REFERENCES}

Adebisi L.O., Jimoh O., Asuquo J., Osasona K.K. and Ojediran E.O. (2019). Effect of contract farming on poultry farming households food security in Osun State, Nigeria. Agro-Science, 18 (1), 45-49. DOI: https://dx.doi.org/10.4314/as.v18i1.7

Baiyegunhi L.J.S. (2015). Determinants of rainwater harvesting technology (RWHT) adoption for home gardening in Msinga, KwaZulu-Natal, South Africa. Water $S A$, (41)1, 33-40

Coomes O.T. and Perrault-Archambault M. (2008). Distribution of agrobiodiversity in home gardens along the Corrientes River. Peruvian Amazon. Econ. Bot., 62, 109-26

FAO (2004). Home gardens: A promising approach to enhance household food security and wellbeing. Food and Agriculture Organisation (FAO), Rome

Galhena D.H., Freed R. and Maredia K.M. (2013). Home gardens: a promising approach to enhance household food security and wellbeing. Agric. Food Secu., 2 (8), $1-13$

Gray L., Guzman P., Glowa K.M. and Drevno A.G. (2014). Can home gardens scale up into movements for social change? The role of home gardens in providing food security and community change in San Jose, California, Local Environment. The Int. J. Justice Sustainability, 19 (2), 187-203

Guitart D., Pickering C. and Byrne J. (2012). Past results and future directions in urban community gardens research. Urban For. Urban Greening, 11, 364-373

Hawkins J.L., Mercer J., Thirlaway K.J. and Clayton D.A. (2013). "Doing"' gardening and "Being" at the allotment site: Exploring the benefits of allotment gardening for stress reduction and healthy aging. Ecopsychology, 5 (2), 110-125

Ibrahim F.D., Oformata A.O., Jirgi A.J. and Adewumi A. (2019). Optimum production plan for maize-based crop farmers in Niger State, Nigeria. Agro-Science, 18 (3), 35-41. DOI: https://dx.doi.org/10.4314/as.v18i3.7 
Idrisa Y.L., Gwary M.M. and Shehu H. (2008). Analysis of food security status among farming households in Ijere Local Government of Borno State, Nigeria. AgroScience, 7 (3), 199-205

Lin B.B., Gaston K.J., Fuller R.A., Wu D., Bush R. and Shanahan D.F. (2017). How green is your garden?: urban form and socio-demographic factors influence yard vegetation, visitation, and ecosystem service benefits. Landscape Urban Planning, 157, 239-246

Marchenko Y.V. and Genton M.G. (2012). A heckman selection-t Model. J. Am. Stat. Assoc., 107 (497), 304-317. DOI: 10.1080/01621459.2012.656011

Marsh R. (1998). Building on traditional gardening to improve household food security. Food Nutritional Agroforestry, 22, 4-14

NPC (2006). Population figures. National Population Commission (NPC) of Nigeria. Published Bulletin, Enugu

Okvat H.A. and Zautra A.J. (2011). Community gardening: A parsimonious path to individual, community, and environmental resilience. Am. J. Comm. Psychol., 47, 374-387

Poulsen M.N., Hulland K.R.S., Gulas C.A. et al. (2014). Growing an urban oasis: A qualitative study of the perceived benefits of community gardening in Baltimore, Maryland. J. Culture, Agric., Food Environ., 36 (2), 69-82

Reyes-García V., Aceituno L., Vila S. et al. (2012). Home gardens in three mountain regions of the Iberian Pninsula: Description, motivation for gardening, and gross financial benefits. J. Sustainable Agric., 36 (2), 249-270

Reyes-Garcia V., Aceituno-Mata L., Calvet-Mir L. et al. (2014). Resilience of traditional knowledge systems: The case of agricultural knowledge in home gardens of the Iberian Peninsula. Global Environ. Change, 24, 223-231
Schreinemachers P., Patalagsa M.A. and Uddin M.N. (2016). Impact and cost-effectiveness of women's training in home gardening and nutrition in Bangladesh. J. Dev. Effectiveness, 8 (4), 473-488

Schupp J.L., Som Castellano R.L., Jeff S., Sharp J.S. and Bean M. (2015). Exploring barriers to home gardening in Ohio households, Local Environment. The Int. J. Justice Sustainability, 41 (34), 1-16

Scott T., Masser B.M. and Pachana N.A. (2014). Exploring the health and wellbeing benefits of gardening for older adults. Ageing Soc., 35, 2176-2200

Tamiru D., Argaw A., Gerbaba M., Nigussie A., Ayana G. and Belachew T. (2016). Improving dietary diversity of school adolescents through school-based nutrition education and home gardening in Jimma Zone. QuasiExp. Design, Eating Behaviors, 23, 180-186

Taylor J.R. and Lovell S.T. (2014). Urban home gardens in the Global North: A mixed methods study of ethnic and migrant home gardens in Chicago, IL. Renewable Agric. Food Sys., 30 (1), 22-32

University of Nigeria Housing Unit (2019). Works Services Department, University of Nigeria, Nsukka

Wang D. and Glicksman A. (2013). "Being grounded": benefits of gardening for older adults in low-income housing. J. Housing Elderly, 27 (2), 89-104

Wang D. and MacMillan T. (2013). The benefits of gardening for older adults: A systematic review of the literature. Activities, Adapt. Aging, 37 (2), 153-181

Zick C.D., Smith K.R., Kowaleski-Jones L., Claire Uno M.L.I.S., Brittany J. and Merrill B.S. (2013). Harvesting more than vegetables: The potential weight control benefits of community gardening. Am. J. Public Health, 103 (6), 1110-1115 